\title{
Urban food markets and their sustainability: the compatibility of traditional and tourist uses
}

\author{
Montserrat Crespi-Vallbona, Marta Domínguez Pérez \& Oscar Mascarilla Miró
}

\begin{abstract}
The aim of this article is to highlight the importance of urban food markets as tourist icons in the current competitive race to create attractive cities. Food markets attract a large number of consumers, both local and tourists. However, their impact on the city and its dynamics should be treated to establish measures to ensure sustainable (compatible) uses for both kinds of users. This calls for the establishment of a system of indicators to determine what level of sustainability food markets are at and facilitate decision-making for the agents involved in their management.
\end{abstract}

KEY WORDS: food markets, sustainability, measuring tool, gastronomic tourism, Barcelona

\section{INTRODUCTION}

Currently, cities compete to attract new activities, more tourists, new residents, etc. One of the tools in this race is local culture (Urry, 1990; Richards, 1996). Among the wide range of cultural aspects, gastronomy is one of the highlights (Bourdieu, 1984; Hjalager 
\& Richards, 2003). To be recognized around the world, food markets have to be authentic, genuine and local. Food plays an important role in everyday activities (both for tourists and for residents) and it is also a pillar of local identity creation and therefore of the cultural specificity that is attractive to foreigners. The food industry offers great opportunities of tourism development (Richards, 2012; Stanley and Stanley, 2015). In addition, tourists have evolved from their contemplative tourism tradition to experimentation where creativity and the local community's lifestyle are included. As a result, culinary experiences are the current trend. However, there is a tension and a balance to be achieved, between the two uses: between being attractive to visitors from different places and cultures of the world, while maintaining local identity and characteristics and responding to the demands of current residents. This is described as standardization versus local identity (Edensor, 1998). In this line, urban food markets appear as a type of tourist resource and regeneration tool of urban centers. They are icons for promoting the image of the city. The objective of this paper is to find the key to ensure the sustainability of these places. When food markets become tourist icons, they run some risks. The most prominent risk of food markets is that of becoming touristified markets, i.e., spaces with a lack of authenticity that are only visited by tourists and ignored by residents. Therefore, the challenge of any destination management organization (DMO) is to look for and preserve the compatibility of the food markets with their duality of uses and users. In order to meet this challenge, a 
measurement system, based on the four different dimensions (socio-cultural, economic, environmental and destination (resource) management), was designed to assess at what level the food market is currently operating. The use of indicators has been widely recognized as an appropriate tool to assess the development and facilitate the operationalization of sustainable policies. Accordingly, a significant number of national and international organizations are getting increasingly involved in the collection and dissemination of several indicator measures. However, this is not happening with regard to food markets, hence, our proposal is the first contribution. In short, the aim of this article is to provide a measuring tool to assess the sustainability of food markets and to enable their reconciliation of uses and users.

The proposed measuring tool serves to find the assessed negative sustainable aspects and to facilitate information to design strategies for the management and monitoring of food markets. Ultimately it intends to seek a sustainable food market management model to ensure compatibility of uses between locals and visitors.

To achieve these objectives, the paper is structured with a section of scientific literature review related to sustainability, gastronomic tourism and food markets. Then 42 synthetic indicators are designed to get information and diagnose about the sustainability status of the resource. The case study of the Boqueria food market in 
Barcelona (Spain) is the illustrative example used for implementing the designed experimental system of indicators and determining its stage. Once the analysis is done, it seeks to implement management proposals to ensure compatible use between local community and tourism. Finally, it is intended to use this measure tool to be applied to other similar resources geared towards sustainability.

The methodology used in the empirical analysis is a combination of quantitative and qualitative techniques, gathering information from secondary as well as primary sources. On the one hand analysis of documentation (municipal ordinances and strategic plans), information published on the website and market brochures, on the other hand information provided by interviews with technical managers of the Boqueria and the Barcelona Municipal Institute of Markets (IMMB), vendors and users, both locals and tourists. Specifically, 4 semi-structured individual interviews were conducted among the Boqueria managers and 8 among the establishment owners; 200 tourists were asked to answer different questions in order to determine the reasons for their satisfaction when visiting the market, and 200 residents were surveyed to know their level of satisfaction or disappointment with the tourist use of the space.

\section{SUSTAINABLE DEVELOPMENT}


The theoretical contributions on the concept of sustainable development are still far from consensus and a clear significance. Therefore, there is a great disparity of definitions (López Palomeque, 2007) and at the same time, a great difficulty in its application. Krippendorff (1977) was the first to refer to the concept of sustainability and later, in 1987, in the World Commission on Environment and Development, the Brundtland Report legitimized and spread this idea. The report considered that sustainable development puts the emphasis on meeting the current needs of humanity without compromising the ability of future generations to find solutions to their own needs. However, the vagueness of this statement and the particular interests of different stakeholders (Wall, 1997) make it difficult to obtain a universal definition of sustainable tourism. The WTO (World Tourism Organization, 2005) states that sustainable tourism takes full account of its current and future economic, social and environmental impacts, addressing the needs of visitors, the industry, the environment and the host communities. In that sense, Sharpley (2000), Liu (2003) or Padin (2012) point out that these needs include both tourists and residents from present to future and also the three dimensions of sustainability: environmental, economic and socio-cultural sustainability. The European Commission (2013) strengthened this approach by introducing the fourth dimension: destination management. Tourists seek a high-quality experience in safe and attractive environments. Therefore the touristic experiences must be monitored and enhanced and DMOs have to look for and protect tourist satisfaction. 
Destination management must be the new dimension to take into account when managing a tourist resource or a destination. Thus, urban planners, as well as tourism managers, need to be aware of and analyze the attributes that attract and motivate tourists in their decisions to visit, just as much as does a destination or a resource (WTO, 2005).

Regarding the economic dimension, it is necessary to take into account the aspects related to the long-term viability of tourism as an economic activity. That is, leverage and consolidation of tourism-generated employment, the direct and indirect effects of the activity; identifying and differentiating the destination for a memorable tourist experience and specific brand (Ritchie \& Crouch, 2003). In the environmental dimension, the aspects involved are the conservation and protection of natural resources and ecosystems to ensure long-term viability. In the case of the social dimension, the observed issues have to do with the welfare of the local population; cultural heritage conservation; community participation in planning and tourism development; and finally, health, hygiene and safety linked to the visit. Finally, the destination management section focuses on issues related to promotion and communication, and visitors' satisfaction. 
To implement a model of sustainable and compatible tourism, it is necessary to know the sustainability status of the resource or destination at a given time. Hence, the importance of sustainability measuring tools. That is, measures that provide relevant information to better understand the links and tourism impacts with respect to the cultural and natural environment in which the activity takes place and upon which it is largely dependent (WTO, 1995). Food markets do not escape this trend and concern. Being aware of the food markets vulnerability when they are becoming tourist icons has to be the main priority of food market managers in order to implement sustainable and compatible policies for both uses and users, that is daily residents' grocery purchasing and visitors' sightseeing. Without such awareness, the touristification, gentrification, disneyfication, museumification or standardization of food halls will expand globally, as has happened with urban historical sites (Zukin, 1995; Petroncelly, 2008; Nelle, 2009; Hiernaux \& Imelda, 2014; Barranha et al., 2017).

The central debate in this article revolves around the issue of the tension between globalization and the local sphere (Harvey, 1989; Giddens, 1990, 1991; Robertson, 1992; Friedman, 1994; Featherstone, 1996), as a stressed dialectical process (Hall, 1991; Giddens, 1991), which can militate against the requirements of sustainability, through the processes of homogenization and consequent exclusion. In this case it is applied to traditional food markets facing the pressure of tourism as a globalizing trend, 
especially in city centers. Whether the scale is tipped, in favor of tourism or local use, the issue is how to find a balance in dynamic and changing urban environments. To be explicit, the question is, whether the food markets move towards scenarios of urban and cultural homogenization or scenarios that respect the local particularity or generate new particularities allowing urban development as a dialectical result while maintaining the inclusion of local communities and the prevalence of their idiosyncrasies, thereby maintaining their sustainability.

Gastronomic Tourism and Food Markets

Gastronomic tourism is a kind of trip whose interest focuses on exploring and enjoying local meals and drinks; to experience typical food of the destinations visited (Ignatov \& Smith, 2006; Long, 2004; Wolf, 2002). The competitive race between tourist destinations around the world to attract more visitors rules the current scenario. Tourist destinations become successful if they conceive the so-called "tourist reflexivity" (Urry, 1995), i.e., if they develop a range of goods and services that can distinguish them from other destinations and appear attractive to potential visitors.

As Crespi-Vallbona and Domínguez-Pérez (2016: 404) state "food markets are exceptional spaces filled with the history and culture of a territory, tastes and eating 
habits of the inhabitants of a destination". Therefore they are significant icons in contemporary cosmopolitan cities as places of intercultural exchange, everyday belonging, and citizenship (Crespi-Vallbona \& Dimitrovski, 2017). They are places where people converge to buy and sell food, conduct business, share news and engage in various social, cultural, economic and leisure practices. In consequence, the cultural tourism trend (Keller, 2005) has also affected traditional food markets. Touristic interest in urban food markets is due to this cultural trend and visitors' demands, just as CrespiVallbona and Dominguez-Perez (2016: 402) assert.

In that sense, high-quality cooking or distinctive local food products play an important role (Hage, 1997; Hashimoto \& Telfer, 2006; Ilbery et al., 2003). Food markets do, as well (Crespi-Vallbona \& Dominguez-Perez, 2016). In fact, as it is said, local foods have a particularly noticeable interest among tourists because they are considered flagship products that capture the typical and identity nature of a particular place (Bessière, 1998; Urry, 1990), where the local population develops its cultural features, which in turn can be viewed and shared by visitors.

Here, food markets play a relevant role, mainly those that are classified as sustainable food markets according to Crespi-Vallbona and Domínguez-Pérez's typology (2016). These sustainable food markets dispense gourmet and ecological goods, as well as 
traditional, healthy and quality groceries, are situated mainly in the center of the cities, and they also provide leisure and culture, aligned with the new lifestyles of the urban middle class residents and tourists. The typology of sustainable food markets only refers to indoor markets; those located in the street, without roof structures, are excluded. The market building has also an artistic and historical interest.

Therefore, food markets become drivers for sustainable urban development (Costa et al., 2015:19) and appear as a new type of resource and tool for the regeneration of urban centers (Dimitrovski \& Crespi-Vallbona, 2017). Furthermore, the rise of gastronomic tourism and travelers' quests to find memorable experiences (Hashimoto \& Telfer 2006; Okumus et al., 2013), lead to the so-called "food-market lovers". These are a new subcategory of food travelers: those tourists who enthusiastically spend a proportion of their holiday time visiting these urban establishments and seeking urban food market experiences (Crespi-Vallbona \& Dimitrovski, 2016: 853).

Although food markets can serve as tourist environments and offer up the local idiosyncratic experience, there are some warning signs related to their conversion into impersonal spaces or "no places" with no differentiation between them: becoming another disneyfied (Zukin, 1998) or museumified (Claval, 1992) part of the city, and hence, part of the homogenization of all urban spaces, entailing themed visual 
coherence, dissolution of particular urban contexts, and a generalized aesthetic overview. This is a highlighted risk of the consequences of globalization.

The current challenge is to provide tourist locations that are full of local culture and gastronomy, without going beyond the limits of sustainability, making these places an ad hoc product for the tourist, without losing their vernacular identity. This difficult balance between both components focuses on how places are perceived, used, and managed (Baerenholdt et al., 2004).

Sustainability of Food Markets: A Measuring Proposal

The key to competitiveness of food markets is precisely ensuring their sustainability and maintaining the balance between popular and traditional public, on the one hand, and tourists, on the other. This is to ensure the compatibility of their applications and users. There are different appropriate methodologies to be used in this multi-criterion decision-making process and to deal with multiple conflicting attributes, as is the case in other sustainability assessments (Diaz-Balteiro et al., 2017). The Weighted Linear Aggregation, with indicator weights can be obtained by subjective methods (Krajnc \& Glavic, 2005), or objective methods (Pulido \& Saìnchez, 2009; Carrillo \& Jorge, 2017). Other methods commonly used are Compromise Programing (Diaz-Balteiro \& Romero, 
2004) or Goal Programing (Blancas et al., 2015; Lozano-Oyola et al., 2012). We chose Goal Programing (GP), due to it being a better method with which to handle multiple conflicting objective measures and optimize decision-making. GP is a multi-objective programing technique first developed by Charnes et al. (1955) and more explicitly defined by Charnes and Cooper (1961). GP is known as a distinguished and effective method of problem solving in any field of multiple variables.

Therefore, our proposed measurement approach is analytical, that is, indicators are established based on the four dimensions of sustainable development (socio-cultural, economic, environmental and resource management) and adapted to food markets to measure their sustainability in order to see their status and what future awaits them. These indicators will help food market managers in their decision-making, determining the desired degree of sustainability in all its dimensions and solving any deviations observed.

The goal is obtained based on the a priori provided information that is, using the given preferences of the analyst, who, based on these preferences, prepares the optimization of the model. Therefore, any assessed issue is connected with a value. This value indicates the level of aspiration or, acceptable or optimum level for the corresponding attribute. This value must reach a minimum (positive sign) or has a maximum value 
(negative sign, since it is the acceptable minimum). This is called setting goals. Then, a priority order is established among all the objectives. This order is determined by the preferences of the decision maker, being a subjective thing and based on the needs and expectations of the organization.

In short, based on the Sustainable Tourism Attitude Scale -SUSTAS- by Choi and Sirakaya (2005), the contributions of White et al. (2010), the European system of tourism indicators (2013) and other studies by academics who have analyzed and measured tourism sustainability (Sirgy et al, 2010; Uysal et al, 2012; Jeon et al., 2016), a system of 42 indicators is proposed to analyze food markets in their four dimensions. The Tables 1, 2, 3 and 4 indicate the basic aspect for each dimension, the specific evaluated question and the conceptual dimension that they belong to. Any indicator has its linked positive or negative value. Each of these synthetic measures is called Synthetic Indicator Goal Programming.

Table 1 lists the issues related to socio-cultural impacts of tourist activity on the resident population and proposes 14 indicators. These issues have to do with the local residents' wellbeing; the health, hygiene and public safety linked to the market visit; and finally, cultural heritage maintenance.

Insert Table 1 
Table 2 identifies 12 indicators related to the economic viability of the market. Therefore, it is analyzed the economic income to the community and market stakeholders; the development and resource competitiveness; and also the supply diversity.

\section{Insert Table 2}

Environmental dimension is represented in Table 3 and lists 9 indicators. The studied aspects are the environmental impact limits and the environmental resource management.

\section{Insert Table 3}

Finally, Table 4 focuses on issues related to tourists' satisfaction and market information and communication. It corresponds to the destination management dimension and proposes 7 indicators.

\section{Insert Table 4}

The positive indicators show a clear health sign of the market in achieving the compatibility of uses; the negative signs must be nuanced, controlled. In this last case, 
the analyst must set a maximum threshold not to be exceeded in order to maintain the compatibility of uses and make these spaces fully sustainable.

For each of the aforementioned negative indicators a limit value has been stipulated to maintain sustainability and compatibility of uses for these spaces. However, for some indicators, it is generically impossible or difficult to provide this value. For example, indicators regarding to the social dimension, for the $\underline{I}_{6}$-Tourist stalls, the threshold not to be exceeded is $15 \%$ of exclusive tourist establishments. But, the $\underline{I}_{7}$-Carrying capacity-, the maximum volume of individuals not to exceed is difficult to calculate, since it is an indoor place, but with completely open accessibility to the public.

This issue, ( $\underline{I}_{6}$-tourist stalls), highlights the importance of limits of acceptable change (LAC). LAC is the degree of change or impact that can be tolerated for the resource, the local community or the visitors. It involves the whole process of defining desired resource conditions and taking actions to maintain or achieve those conditions. Middleton and Hawkins (1998) defined carrying capacity as a measure of the tolerance of a tourist site and the limit beyond which it may suffer from adverse impacts. Therefore, the LAC framework has been used to monitor tourist activities and sites by identifying standards of quality and placing emphasis on positive planning and management anticipating overuse. Therefore, this approach to managing impacts is 
based on the amount of change to be allowed in particular settings and developing monitoring to assess these changes. Both physical indicators and users' perceptions are informational sources of social indicators and their acceptable thresholds.

Many research projects have been conducted, analyzing impacts, to promote a sustainable balance between environmental and social needs (Stankey et al., 1984; Diedrich et al., 2011; Bentz et al., 2011; Massiani and Santoro, 2012). The current study explores the use of LAC to safeguard the sustainability of food markets, and proposes an appropriate and acceptable proportion of stalls aimed at visitors, to avoid their touristification $(15 \%)$.

The tourism carrying capacity (TCC) is the other key factor in measuring the sustainability of any resource. TCC is defined as the maximum number of people that may visit a tourist destination at the same time, without causing destruction of the physical, socio-cultural and economic function in the local community and environment or prejudicing the crucial balance between development and conservation. In statistical terms, it is the number of visitors that can be accomodated in a place at any peak time without resulting damaged to the attraction (World Tourism Organization 1992, quoted by Echamendi (2001)). The result is not an absolute number of visitors (Getz, 1983; Cifuentes, 1996), but a range of levels of appropriate tourist use. For some specific resources, managers are forced to adjust intuitively in situ the access to these places 
(García Hernández and Calle Vaquero, 2012: 255-256). Saveriades (2000) suggested that the restriction of tourist numbers provides an important carrying capacity management approach, whereas, Abernethy (2001) stated the concept is deficient, unquantifiable and inapplicable.

In any case, carrying capacity management implies a model of socially, culturally, environmentally and, economically sustainable use (Getz, 1983; Glasson et al., 1995; Cifuentes, 1996; Abernethy, 2001), where an increase in visitors does not adversely affect either the resilience of the attraction and the resident community or the satisfaction and quality of the tourists' experience (Chamberlain, 1997; Segrado Pavón et al., 2015). Therefore, according to Saveriades (2000), authors who have attempted to determine carrying capacity have emphasized local community and culture, the site's physical characteristics and the quality of visitors' perceived experience (Shelby et al., 1989; Vaske \& Donnelly, 2002). There are some studies of sustainable carrying capacity models based on indicators (Castellani \& Sala, 2012), focused on cities or tourist destinations. The method of Cifuentes (1996), based on the optimum level of tourist utilization, has been widely applied in nature parks and public spaces (Nghi et al., 2007; Segrado \& Arroyo, 2009; Schlüter \& Drummond, 2012; Sayan \& Atkim, 2011; Marozzi et al., 2011; Garcia et al., 2011). The scholars propose a measuring tool to assess the carrying capacity for tourism resources, from the real to the effective 
carrying capacity and the manager's criteria $(2012,263)$. Their proposals also take into account three dimensions of analysis: 1) territorial, 2) ecological and 3) administrative. The result is a maximum number of people that the administration can manage without incurring negative impacts on the tourist site. Thus, in the case of food markets, determining the real and affective social and tourist carrying capacity depends on the actual size of the corridors (taking into account packages, boxes, trolleys and employees working in front of the stalls). It is not possible to establish a generic threshold in these cases, because each market has a specific size of corridors.

\section{THE CASE STUDY OF THE BOQUERIA FOOD MARKET IN BARCELONA (SPAIN)}

The Boqueria food market in Barcelona is analyzed to check its sustainability level and to propose, if they are needed, the required corrections. The market is located on the Rambles, one of the most touristic avenues of the city. It is designated as a tourist attraction not to miss in different websites, guidebooks, tourist brochures, personal blogs, etc. and is classified as a sustainable food market due to its duality of uses and users.

The IMMB (Barcelona Municipal Institute of Markets) is an autonomous agent, which manages the 44 municipal markets of Barcelona. La Boqueria is one of them. This 
autonomy is exercised at the administrative level (the own budget management) and in the field of regulation. To this end, the new municipal ordinance about markets, which updated the former ordinance (from 1968) and redefined the markets, their establishments and types of goods, sellers' rights and duties, etc., was approved in January 2009. Similarly, the IMMB has carried out a remodeling, modernization and updating project of all the municipal markets. In the specific case of the Boqueria, the IMMB has remodeled the nearby urban area creating an underground car park and a public area with benches and trees, where many tourists take the opportunity to rest and eat.

\section{Methodology}

To analyze the state of the Boqueria market following the proposed indicators of sustainability and compatibility of uses, the municipal Ordinance referring to Barcelona Markets and the urban environment ordinance have been analyzed, and interviews have been conducted with the responsible managers, specifically the head of communication and the head of research and strategy (these two interviews were conducted on $6^{\text {th }}$ November 2015), as well as the Boqueria market manager $\left(16^{\text {th }}\right.$ November 2015$)$, and the technicians responsible for certifications and health checks of establishments $\left(17^{\text {th }}\right.$ November 2015), from the Barcelona Public Health Agency (ASPB). These four roles represent the management and administration of the whole group of Barcelona markets 
and the specific management of La Boqueria, respectively. The main purpose of these semi-structured interviews was to get as much information as possible related to the four sustainability dimensions, according to their strategic positions. Therefore, the interview was structured following the four sustainability dimensions and the issues referred into within each of them.

Importance has also been given to various market vendors' interviews (specifically eight owners) from both sectors, those targeted to tourism goods and those more traditional (equal pairs), that is, the most happy and optimistic and also the most upset and negative, due to their high or low income, respectively (these interviews were conducted between $16^{\text {th }}$ and $20^{\text {th }}$ November 2015). Their comments were highly significant, emphasizing both the advantages and the inconveniences of tourism, according to their level of economic profitability and also regarding their business essence: a) bars and ready meals, b) fruits and vegetables, c) poultry, meat and charcuterie, and d) fish. The vendors' association gave us the information related to the economic relevance of each of these establishments. The structure of the interview followed the aforementioned format used with market managers.

Neighbors' and tourists' impressions have also been collected and analyzed. Related to the tourists' impressions, this research collected a sample of 200 respondents, tourists 
who visited La Boqueria in Barcelona, on different days and hours of the week (except weekend), from Monday to Friday, mornings and afternoons, from $9^{\text {th }}$ March to $17^{\text {th }}$ April 2015. The questionnaires were distributed both at the main entrance and along the different aisles within the market. They were asked to answer 16 questions (grouped into social, environmental and resource management dimension) in order to determine the reasons for their satisfaction when visiting the market. In particular, respondents expressed their level of agreement on a seven-point Likert scale ( $1=$ strongly disagree, and $7=$ agree absolutely, with each given premise). The questionnaire took into account questions in the social, environmental and resource management dimensions as travel motivator factors, according to the research of Dimitrovski and Crespi-Vallbona (2017).

Also in this same period, and following a similar methodology, 200 residents who were regular buyers at the Boqueria market, were surveyed, in order to know their level of satisfaction or disappointment with the tourist-oriented use of the space. Specifically, this questionnaire posed 19 questions (also grouped in social, economic and environmental dimensions) and the survey was conducted on different days and hours of the week, from Monday to Saturday, mornings and afternoons, between $9^{\text {th }}$ March and $17^{\text {th }}$ April 2015. Respondents also expressed their level of agreement with each given premise, on a seven-point Likert scale (where $1=$ strongly disagree and $7=$ agree absolutely). The questionnaire structure was as follows. Concerning environmental 
costs, several questions considered were related to the building's deterioration and degradation, vandalism, littering, dirt, pollution, pilferage, exceeding the infrastructural carrying capacity, and noise (Jurowski et al., 1997; Gursoy et al., 2002, 2004; Sirgy et al., 2010; Uysal et al., 2012; Jeon et al., 2016). Relating to the socio-cultural dimension, questions were based on the increase in pride and cultural identity, the interaction of different cultures, and the conservation and revitalization of local culture (CrespiVallbona \& Richards, 2007; Berno \& Ward, 2005). Finally, in the economic dimension, new jobs, business and investment opportunities, and income were covered (Ko \& Stewart, 2002; Andereck et al., 2005; Frauman \& Banks, 2011; Látková \& Vogt, 2012; Zhou et al., 2015).

Findings

In the analysis of the collected information in relation to the 42 proposed indicators, it was found that the Boqueria retains its essence as a food market for local use and shares its usability with tourists. However, there are some negative indicators that should be evaluated in this case, such as the sustainable carrying capacity and the limit of acceptable change. This shows how this tool can help to evaluate the sustainability of the food markets. 
So, firstly, taking into account the social dimension, we analyzed who goes to these places and why, and what their characteristics are. The public that attends this equipment is the Barcelona population and tourists. Anyway, the calculation of the exact number of visitors is complex and it cannot be accurately established. The Boqueria is an indoor market, but fully open, so it is not possible to know what number of users regularly accesses this hall without distinguishing between residents and tourists. However, the market managers estimate that on Fridays and Saturdays 2,000 people visit the market per day. This amount rises to 5000 on Mondays from April to October with cruise-ship passengers. The influx of visitors is so great that sometimes it is difficult for the residents to do their shopping, for the vendors to sell and for tourists to visit the market. Therefore, it exceeds the social carrying capacity $\left(\mathrm{I}_{7}\right)$. Thus, it is not possible to calculate the market carrying capacity, although the current Evacuation and Self-Protection Market Plan states that a total of 4 people fit in its aisles. To address this aspect of social sustainability, the local government has just approved a decree limiting visits by organized groups of 15 or more tourists on Fridays and Saturdays, between opening time and $3 \mathrm{pm}$. The aims are to protect the use of this space by residents to encourage proper development of market activity and to avoid structural damage within the hall (Regulation of Access to the Boqueria Municipal Market, April $2^{\text {nd }} 2015$ ), in order to achieve an appropriate level of tourist use of this space (Cifuentes, 1996, 2012). 
However, the different sizes of the corridors make it difficult to determine the real and effective carrying capacity, due to there being no feasible way to establish the applicable number of packages, boxes, trolleys or employees working in front of the stalls.

Regarding the Boqueria supply that determines the market inclination towards one type of public or another, results show that of the total of 257 stalls in the Boqueria, $85 \%$ serve traditional goods: meat, fish, seafood, fruits and vegetables, etc. The remaining $15 \%$ offer goods focused on tourism, like ready-made meals; fruit juices; trays of readycut fruit pieces; chocolates, etc. These stalls focused on tourism goods are located in the first three aisles near the Ramblas (the main entrance); bids are written in English and Catalan or Spanish, since the structure has been renovated and modernized, and employees are usually young people with foreign language skills. They are therefore more visible. Consequently, a limit of acceptable change (LAC) has been introduced $(15 \%)$ to identify an optimum threshold of tourism tolerance and impact containment (Middleton \& Hawkins, 1998) and to slow down the food market's touristification or disneyfication (Zukin, 1995, 1998).

In any case, the more traditional establishments (or not only specialized in tourists) occupy the rear and side aisles. Some of these stalls are not modernized, their 
employees are often the owners (who have inherited the property and go on with the family tradition), and some of them have an uncertain and difficult future.

In this line and based on the residents' survey (200 respondents), $71 \%$ said that tourism bothers them in their daily shopping activity. Similarly, $72 \%$ believe that the tourist crowd congests the market. Finally, $85 \%$ of respondents believe that due to tourism, prices of market goods have increased.

As for its schedule and its conditioning for the influx of visitors, the timetable is broader than other commercial centers (until $21 \mathrm{pm}$ ), from Monday to Saturday. The Boqueria opens on Mondays, when the rest of the city markets are closed, and in fact this day has become the third best day in terms of sales, behind Fridays and Saturdays, the regular shopping days of the week.

About the ease of accessibility to the market, it should be noted that people can access the market by public transport (bus and underground) and there is a car park ensuring that residents of other neighborhoods can buy their groceries at the Boqueria. However, accessibility and adaptation for disabled are not total, specially referring to old people which are one the main users of the market. Not all of the eight market accesses are equipped with ramps for people with reduced mobility; only $70 \%$ of entrances are 
available for them. The central corridors are wide for people who have to move in a wheelchair. However, lateral aisles are narrower, and when boxes, trolleys or other obstacles accumulate, the accessibility drops. There are neither lines marked on the floor with different contact for the blind people; or tactile screens and informative panels with Braille language. Also, the $74.5 \%$ of respondents believe that the market security level is acceptable or correct. In fact, it has two security guards 24 hours a day, as well as video surveillance.

Regarding cultural and leisure activities that serve as a claim and also boost citizen participation, the Boqueria has, on the first floor of the building, a space for cultural activities, gourmet cooking courses and workshops for both residents and visitors. BcnKITCHEN is the name of the organization that offers these services. Finally, in this section of social indicators, one of the highlights of the market is its artistic and historical interest which gives identity features to the local population and serves as an attraction to tourists. Although the building itself has not been declared a Cultural Site of National Interest (BCIN), the main entrance and some of its stalls are in the modernist style, and the architectural body that shelters the market according to neoclassical parameters, has an artistic and historical interest to both tourists and residents. The two users value this tangible heritage very high, $71 \%$ and 88 '5\% respectively. 
With regard to the economic dimension, all indicators have a positive sign. As for the market profitability and its contribution to sustainable local economy, IMMB estimates a global turnover of 95-100 million euros per year, with an average of $€ 400,000$ per establishment, despite of the variability. Thus, the stalls that address their goods to tourists have a revenue volume of $95-100 \%$ of their total sales. For example, any juice stall sells 1000 glasses per day (2 euros each) on a day of little influx of tourists; on maximum visit days this same stall can sell 3000 glasses, which coincides mainly with Mondays, the day cruise-ships arrive at the city. Bars also focus their income on tourists, $95 \%$ of the total amount. The remaining $5 \%$ comes from the market vendors, who usually have their coffee, eat breakfast and even have lunch. Moreover, some traditional establishments have enabled a small part of their stalls to tourist goods (only $5 \%$ of the total), such as selling paper cones with cut sheets of Serrano or Iberian ham, and restock this product 20 times a day, so its sales volume is very noticeable. In fact, these sales represent between $50-70 \%$ of their total business.

As for employment generation, the market offers different employment options. Of the total number of 257 stalls none are closed and all are private properties. The Municipal Ordinance of Markets does not allow stall rentals, and establishes a sanction of losing the right to sell on the market. Although there is no specific data, it is estimated that 
about 725-750 employees work in the market. It is also to be considered that on Fridays, Saturdays and Mondays the establishments hire extra staff to cover the needs of the service. The average is between one and eight workers.

As for the typology of the establishments, it is found that a significant number of stalls cater only to new customers (15\% of establishments): fresh juices, fruit cut into pieces, takeaway meals, sweets, candies and chocolates, etc., that is, different goods that tourists can easily consume during their visit. Traditional stalls of meat, fish, fresh fruits and vegetables, and other products of recognized quality (mushrooms, spices, nuts...) represent $50 \%$ of the total. The remaining $35 \%$ combine local and traditional goods with tourist fare. In that case, a small part of their display cases is dedicated to ready-made food for tourists, but the rest is exclusively intended for residents. $25 \%$ of the establishments sell their own locally produced goods, almost all vegetables. The remaining stalls provide fresh goods, food mile (such as cherries from Sant Climent, beans from Maresme, artichokes from El Prat, peas from Llavaneres, cold meat from Moià, etc.) and international goods (mainly Greek and Latin American).

Regarding the environmental dimension, there are some negative indicators that must be controlled, such as the waste disposal, the noise and air pollution, etc. For example, the market does not have tanks for collecting wastewater. They exist in the city, but not in 
the market itself. Neither does the market collect rainwater. As for selective waste collection, the Boqueria has one of the most modern systems, with a compacting system for cardboard / paper, one for organic waste and one for special waste. Twice a day, these containers are emptied directly by the Department of Environment for treatment. The only thing that is not collected separately is glass, since it is not a usual material in market establishments, except bars. However, they have urban glass containers close to the market. On the other hand, diurnal noise pollution is below the acceptable threshold, since music is prohibited in the stalls and market loudspeakers are only occasionally used, just in emergency cases. Even so, the market doesn't work before 8 am or after 21 hours. While from 21 to 24 hours it is necessary to clean the market, the noise is not excessive and lies within the allowed threshold. Also, being closed at night, the market does not create any nighttime noise pollution. Air pollution is characteristic of any food market. And although ventilation is deficient, since it should reach 30-40 meters as regulations indicate, due to the market structure, the established outdoor contamination values are not exceeded.

Regarding cleanliness, the residents' and tourists' opinion is positive. $66 \%$ of surveyed residents believe that the level of cleanliness of the market is good or right. As for tourists, $75 \%$ are satisfied with the cleanliness of the market. There are two types of cleaning services. One company that deals with the market and is paid by the Boqueria 
Sellers Association and a reinsertion company paid by the City Council, through the autonomous body, the Barcelona Municipal Institute of Markets. The latter enterprise collects tourist wastes daily, at 11 am and $19 \mathrm{pm}$ : wrappers of prepared food trays, plastic cups of juice, paper cones, etc. To this purpose, there are 10 additional containers.

The Barcelona Public Health Agency is in charge of the health and safety control of stalls that provide prepared food. The establishments display the distinctive Health Certificate and are also subject to periodic inspections by the Agency. Similarly, the bakery stalls that prepare cooked foods do have ISO quality certification.

Finally, looking at the dimension of resource or destination management, it is found that the Boqueria market has several resources that advertise and indicate the place as attractive. There is a website, in Catalan, Spanish, French and English; the market also offers promotional videos and is present in social networks. However, the historical and artistic explanation of the architectural complex is nonexistent, except for the main entrance, with a commemorative plaque in Catalan, which is highlighted as a negative indicator. 
Similarly, the market has a center of information about market stalls and it sells merchandise such as garment bags, magnets, mugs, etc. As for satisfaction and repeat visits, $93.5 \%$ of respondents think that their visit experience is authentic, that they have perceived many opportunities to learn about local culture and culinary habits, and consider their experience a pretty and highly rewarding visit. Among them, $62.5 \%$ visit the Boqueria market for the first time and the remaining $37.5 \%$ repeat. $62.5 \%$ of respondents consider that the value for money ratio of the offered goods is good, acceptable.

\section{DISCUSSION AND CONCLUSION}

Destinations are launched as visitor attractions promoting of their cultural and touristic heritage to capture new investments in a framework of prevalence of the cultural paradigm (Touraine, 2005; Bauman, 2011). Food markets do not escape this trend. The so-called sustainable markets are those that present the most risk of becoming touristified, gentrified markets, losing their essence and singularity, due to their remarkable position as touristic icons. The urban food markets are part of the cultural landscape (Pujia, 2016) since they are indispensable to an understanding of the identity of a particular territory. They are usually historic places, featuring plenty of local custom, and socially dynamic heritage (popular traditions, gastronomic habits, social 
interrelations, etc.). There are not many previous studies regarding the food markets as touristic icons and none related to the need to preserve their sustainability and compatibility of uses and users. The problem is that this situation is not a snapshot but a process. We mean that there is an ongoing process of change which can become a public and political issue.

Therefore, the aim of safeguarding those food markets classified as sustainable, that is, those food markets that coordinate dual uses and user groups, (regular who purchase their daily groceries, as well as organized and occasional tourists), leads the researchers to establish a system of indicators to determine at what level of sustainability they are operating. La Boqueria Food Market in Barcelona is the illustrative case and the starting point of the proposal for a new preservation model of sustainable markets. That is, a proposal of sustainable food market management focused on the limits of acceptable change (LAC) and the tourist carrying capacity (TCC). Both TCC and LAC deal with undesirable impacts of tourism on food market utilization and both set standards on how this resource should be managed to maintain a sustainable state.

The analysis of the 42 indicators concludes that the Boqueria success lies in its location in the tourist center of the city and its adaptation to new users. Its classification as a sustainable market is due to its compatibility of uses that must be guaranteed in the future. The proposed indicators are used to detect which aspects are vulnerable in order 
to find a solution and allow the market to remain a benchmark for residents when shopping for their groceries, while remaining a milestone for tourists during their visit to the city of Barcelona. This case is a demonstration that this tool can serve to evaluate the sustainability of markets as well as point to those issues that require correction or transformation.

These sustainability-measuring indicators indicate that the Boqueria market still remains as a sustainable market. However, it offers two different worlds. Establishments located in the first three corridors near the Ramblas (the main entrance) live off tourism. The rear and lateral aisles follow the pattern of a traditional local market. The tourist pressure on the overall market represents $15 \%$, the maximum threshold, as the LAC proposed (following Middleton \& Hawkins, 1998). But the perception of this by resident users is greater, fuelling animosity and discontent towards tourists because of congestion in the aisles, the exceeding of carrying capacity, and the price increase of goods. Related to the price increase of goods, it should be noted that these increases mainly occur in just those $15 \%$ of establishments focused on tourists.

Clearly, the Boqueria management must be oriented toward a limit of change among the stalls, but all the while, seeking consensus among all the establishment owners. Because food market managers cannot exclude the traditional stalls that resist tourism or their 
type of goods does not allow them to adapt. In these cases, they stoically survive. The range of neighbors, who buy at their establishments, is mainly elder and immigrant people, who form the majority in the local surrounding communities. The Boqueria location makes it difficult to successfully continue as just a traditional market. The Boqueria is situated in the Barcelona tourist heart and at the edge of the Raval district, with a predominant Muslim population, which buys in Halal shopping centers. The chicken stalls, butcher shops, and traditional fishmongers are the establishments most affected in their daily work. In short, the Boqueria is maintained thanks to tourism and the specialized, food mile and local quality goods. Butchers and nut shops have adapted and included a service variant to new customers: tasting as the emblem. Another example is the tripe and offal stalls that survive thanks to Latin Americans and Africans, their current traditional customers, because their diets include these ingredients. The feature of multiculturalism within the neighborhood is mirrored within the market. Furthermore, these tripe and offal stalls have reinvented their businesses: ready-made dishes to local residents, who don't have time for cooking or do not know how to do it. Other stalls are well-known around the Barcelona population due to their goods: hunting birds, mushrooms or pâtés; others are involved with the Foursquare app for customers which look for buying or visiting the best places of cuisine around the world. In the latter case, it is clear that gentries or upper middle classes play an important role. It is clear that this specialization and adaptation is the key to the 
market's continuity and success (Costa et al., 2015; Dimitrovski \& Crespi-Vallbona, 2017).

But undoubtedly the Boqueria resists deterioration due to the influx of tourists. And despite of them (or because of them), the traditional establishments exist, adapting to the changing needs of these consumers, with fried fish skewers, paper cones with Serrano or Iberian ham slices, natural fruit juices, etc. This new, good preparation and presentation guarantees the vendors a generous percentage of their total turnover. Moreover, modern urban society's buying habits have changed: the midday meal is no longer made at home; the weekday grocery purchase is limited to a radius of 400 meters walk, and therefore people usually shop in supermarkets and usually prefer ready-made food in order not to have to cook.

Tourists can consume a juice or a tray of sliced fruit, but what they expect from their visit to the market is to know the locals' eating habits, as well as to compare the fishmongers, delicatessens, butchers, specialized stalls, etc. with the ones of their own culture. Without these traditional establishments, the food market loses its prestige, its cachet, and tourists disappear from the scene. $15 \%$ of all stalls may not seem a high proportion, but it is true that the way they show and exhibit their goods makes them highly visible, and the touristification and loss of authenticity is magnified. 


\section{MANAGERIAL IMPLICATIONS}

These indicators are one useful tool to prevent the touristification or disneyfication (Zukin, 1995, 1998) of food markets, especially those that have been classified as sustainable markets attracting different kinds of users, tourists and residents (CrespiVallbona and Domínguez-Pérez, 2016).

The dilemma is that the Boqueria is attractive due to its traditional stalls: butchers, fishmongers, greengrocers, etc. Without these establishments, the market would lose its authenticity and interest. Therefore, it is recommended enabling and readapting these stalls to reach a balance in their dual use. Since the City Council and the Barcelona Municipal Institute of Markets as the Vendors Association are fully aware of this situation, they have to join forces and continue providing their services to both audiences. That is, their union has the obligation to prevent the Boqueria's disneyfication on touristification. In that sense, the proposed indicators represent a useful tool for the Boqueria managers and stakeholders to detect the turning point of its sustainability and to influence and ensure its idiosyncrasy and authenticity. That is, they have to keep offering local and traditional goods to Barcelona neighbors, but without 
excluding tourism. Food markets used to have an authentic essence, they showed the specific idiosyncrasies of local culture, the singular atmosphere, tastes and habits of a territory. Therefore, they have to be preserved in order to answer tourism's demands and expectations related to cultural (Keller, 2005) and gastronomic (Richards, 2012; Stanley \& Stanley, 2015) trends. Food markets exhibit plenty of sensory stimuli that elicit emotions connected to taste, smell, sight, touch and even hearing. They promise great, unique, memorable experiences. Therefore, food market managers must focus their efforts on all of these aspects and legislate to preserve tourists' memorable experiences (Tsai, 2016). If not, the danger is that the memorable experiences may disappear.

In conclusion, a specific ordinance for the Boqueria is needed to maintain the sustainability and compatibility of uses and users. It is also needed to survive in the group of sustainable markets. One of its negative indicators is the limit of acceptable change ( $\underline{\mathrm{I}}_{6}$-tourist stalls), and the other is the maximum flow of people ( $\underline{\mathrm{I}}_{7}$-carrying capacity), that is exceeded at certain times of the day and in specific seasons. To correct the first negative indicator, a specific ordinance is required that regulates the Boqueria adaptation to the new reality of users in order to maintain the existing compatibility of uses. It should emphasize avoiding unfair competition between what is fresh and what is prepared and/or precooked. Establishments should not offer ready-made meals if they don't already sell the main fresh ingredients. Thus, the basic character of the 
establishment and the market will not be lost. This should also lead to the disappearance of exclusive tourist stalls. There could be a limited of fresh goods to prepared/cooked meals at a minimum rate of $50 \%$.

The other seriously negative indicator has to do with the maximum carrying capacity that the market can accommodate. According to estimations, in poor days, about 1,000 people visit the food hall; and 5,000 tourists during more generous days. Then, the crowd, congestion and saturation are manifest. Major renovation, such as an expansion of the corridors, cannot be carried out because it is a historic site. Notwithstanding, this is one of the common complaints among residents. Aisle enlargement would make it possible to puff up the crowds of visitors and residents and reduce the discomfort of neighbors and sellers who work (with boxes, carts and other packages). In this sense, market managers should recover licenses from owners that want to sell their property to get a free zone or space within the market, and thus decongest traffic areas.

The City Council approved a decree to relieve people saturation in the indoor passages (mainly from the main entrance, the Rambles). This decree prohibits organized groups (of 15 people or more) on Fridays and Saturdays from opening until 15 hours from visiting the market. Not on Mondays. However, the result is ineffective. These tourists come in the market in a more or less separate or individual way through the entrance 
(under the watchful eyes of the security forces) but gather two aisles further down to continue the tour with the rest of the group, following the guide's explanations. Therefore, the collapse in the passages or the main entrance still remains. In that sense, managers should redistribute visitors in a more balanced way. There are needed visible indications of the other two entrances that exist on the Rambles, in order to decongest the accesses and lead tourists to stroll on the rest of the aisles. Also, interpretive and informative panels are required to explain the historical and artistic value of the market in different languages.

\section{LIMITS AND FUTURE RESEARCH}

This research is mainly concerned with evaluating the sustainability and the risks of touristification and disneyfication of a touristic and local resource within an urban setting, namely the Boqueria food market using a proposed methodological tool. In this way, we have analyzed the Boqueria as a case study in order to propose our methodology for other cases across cities. We aim towards the non-disappearance of traditional stalls (the attractive base for tourists), facilitating adaptation and reinvention of the business to new consumers, without forgetting the traditional users. It would be fruitful to study the level of sustainability of other urban food markets to implement new management policies in benefit its sustainability, mainly those that consist of dual uses and users, i.e., residents' local shopping needs and tourists' cultural explorations. 
Hence this proposed measuring tool to assess the level of sustainability of food markets can be considered good practice to be extended to other cases such as the touristified markets of San Miguel or San Anton in Madrid. Even those markets that could be susceptible to losing their essence, their singular soul, such as San Fernando or Anton Martin in Madrid, or La Barceloneta, Sant Antoni or Santa Caterina in Barcelona, could benefit, as they change and re-define their characters. Also, this methodology can be applied to other cities and countries, just for example Les Halles Saint-Géry in Brussels or the Mathallen in Oslo.

Furthermore, in the future, it would be interesting to analyze the foodtruck trend. It is another example of the drive to regenerate and revitalize urban spaces, following the current gastronomic momentum, yet as a new phenomenon, it is more dynamic and flexible.

\section{FUNDING}

This work was supported by the Regional Government of Catalonia, Research Group in Organizations, AQU_SGR1550; by the Ministry of Economics and Competitiveness of Spain, "Social changes and processes of urban transformation in a crisis context in suburbs of big metropolitan areas in Spain. The case of Barcelona Metropolitan Network -RMB-" project [grant number CSO2013-48075-C2-1-R]; and also by 
Regional Government of Madrid and the European Social Fund (ESF) with the Project

"Vulnerability, participation and citizenship. Keys to a Sustainable Urban Development 2016-2018 " [grant number S2015/HUM-3413) (www.vupaci.com ).

\section{REFERENCES}

Abernethy, V. (2001). Carrying capacity: The tradition and policy implications of limits. Ethics in Science and Environmental Politics ESEP, 23, 9-18.

Andereck, K. L., Valentine, K. M., Knopf, R. C., \& Vogt, C. A. (2005). Residents' perceptions of community tourism impacts. Annals of Tourism Research, 32(4), 1056-1076.

Baerenholdt, J., Haldrup, M., Larsen, J. and Urry, J. (2004). Performing Tourist Places. Ashgate Publishing

Barranha, H. Caldas, J. V., Neto da Silva, R.N. (2017). Translating heritage into museums: two architectural strategies inside Lisbon Castle, Journal of Cultural Heritage Management and Sustainable Development, 7 (1), 33-47.

Bauman, S. (2011). El País, cultura. 38 vida \& artes, septiembre

Bentz, J., Rodrigues, A., Dearden, P., Calado, H. and Lopes, L. (2015). Crowding in marine environments: divers and whale watchers in the Azores, Ocean Coastal Management, 109, 77-85

Berno, T., \& Ward, C. (2005). Innocence abroad a pocket guide to psychological research on tourism. American Psychologist, 60, 593-600.

Bessière, J. (1998). Local development and heritage: traditional food and cuisine as tourist attractions in rural areas. Sociologia Ruralis 38(1): 21-34.

Blancas, F.J., Lozano-Oyola, M. and Gonzailez, M. (2015). A European sustainable tourism labels proposal using a composite indicator. Environment Impact Assessment Review, 54, 39-5

Bourdieu, P. (1984). Distinction: A social critique of the judgement of taste. Harvard university press.

Carrillo, M. and Jorge, J. (2017). Multidimensional Analysis of Regional Tourism Sustainability in Spain, Ecological Economics, 140 (89-98)

Castellani, V. and Sala, S. (2012). Carrying capacity of tourism system: Assessment of environmental and management constraints towards sustainability. In (ed.) Murat 
Kasimoglu. Visions for global tourism industry - creating and sustaining competitive strategies. Rijeka, Croatia

Castells, M. (1996). The information age: Economy, society, and culture. Volume I: The rise of the network society.

Claval, P. (1992). The museification of landscape. Geoscience and Man, 31, 335-351.

Chamberlain, K. (1997),. Carrying capacity, UNEP, Industry and Environment 8. Paris: UNEP.

Choi, H.S. and Sirakaya, E. (2005). Measuring residents' attitude toward sustainable tourism: development of sustainable tourism attitude scale. Journal of Travel Research 43: 380-394.

Cifuentes, M. et al. (1996), Determinación de la capacidad de carga turística en los sitios de visita del Parque Nacional Galápagos. Servicio P.N.G. Ecuador.

Crespi-Vallbona, M. and Dimitrovski, D. (2017). Food Markets from a Local Dimension -La Boqueria (Barcelona, Spain). Cities, (70), 32-39.

Crespi-Vallbona, M., \& Dimitrovski, D. (2016). Food markets visitors: a typology proposal. British Food Journal, 118(4), 840-857.

Crespi-Vallbona, M. and Domínguez-Pérez, M. (2016). Los mercados de abastos y las ciudades turísticas. Pasos. Revista de turismo y patrimonio cultural 14 (2): 400416.

Crespi-Vallbona, M., \& Richards, G. (2007). The meaning of cultural festivals: stakeholder perspectives in Catalunya. International Journal of Cultural Policy, 13(1), 103-122.

Costa, N., Mackay, M., Martín, O., Navarro, G., Partridge, A., Portinaro, A. and Scheffler. N. (2015). Urbact Markets. Urban Markets: heart, soul and motor of cities. Barcelona: IMMB

Diaz-Balteiro, L., Gonzaìlez-Pachoìn, J. and Romero, C. (2017). Measuring systems sustainability with multi-criteria methods: a critical review. European Journal of Operational Research, 258, 607-616.

Diaz-Balteiro, L. and Romero, C. (2004). In search of a natural systems sustainability index. Ecological Economics, 49, 401-405. 
Diedrich, A., Balaguer Huguet, P. and Tintore Subirana, J. (2011), Methodology for 
applying the Limits of Acceptable Change process to the management of recreational boating in the Balearic Islands, Spain (Western Mediterranean), Ocean Coastal Management, 54, 341-351

Dimitrovski, D. and Crespi-Vallbona, M. (2017). Role of food neophilia in food market tourists motivational construct. The case of La Boqueria (Barcelona, Spain), Journal of Travel and Tourism Marketing, 34 (4), 475-487.

Featherstone, M. (1995). Undoing Culture: Globalisation, Postmodernism and Identity. Sage, London.

Frauman, E., \& Banks, S. (2011). Gateway community resident perceptions of tourism development: Incorporating importance-performance analysis into a limits of acceptable change framework. Tourism Management, 32(1), 128-140.

Echamendi, P. (2001). La capacidad de carga turística. Aspectos conceptuales y normas de aplicación, Anales de Geografía de la Universidad de Complutense, (21), 11-30.

Edensor, T. (2008). Tourists at the Taj: Performance and meaning at a symbolic site. Routledge.

García, M. and Calle, M. (2012). Capacidad de carga en grandes recursos turísticoculturales. Anales de geografía 32 (2): 253-274.

García, M., Calle, M. y Mínguez, M. (2011). Capacidad de carga turística y espacios patrimoniales. Aproximación a la estimación de la capacidad de carga del Conjunto Arqueológico de Carmona (Sevilla, España)". Boletín de la Asociación de Geógrafos Españoles, 57 (2011), 219-241

Getz, D. (1983). Capacity to absorb tourism: concepts and implications for strategic planning, Annals of Tourism Research, 10, 239-263.

Giddens, A. (1990) .The Consequences of Modernity. Polity, Cambridge.

Giddens, A. (1991). Modernity and Self-Identity. Polity, Cambridge.

Glasson, J., Godfrey, K. and Goodey, B. (1995), Towards Visitor Impact Management: Visitor Impacts, Carrying Capacity and Management Responses in Europe's Historic Towns and Cities. England: Avebury.

Gursoy, D., Jurowski, C., \& Uysal, M. (2002). Resident attitudes a structural modeling approach. Annals of Tourism Research, 29(1), 79-105.

Hage, G. (1997). At home in the entrails of the West. In Grace H (ed) Home/World: Space, community and marginality in Sydney's west. Annandale, NSW: Pluto.

Hall, S. (1991). Old and new identities: old and new ethnicities (44-68). In King, A.D. (ed.) Culture, Globalisation and the World-System. Macmillan, London.

Harvey, D. (1989). The Condition of Postmodernity. Basil Blackwell, Oxford.

Hashimoto, A. and Telfer, D.J. (2006). Selling Canadian culinary tourism: Branding the global and the regional product. Tourism Geographies, 8 (1), 31-55.

Hjalager, A. M. \& Richards, G. (Eds.). Tourism and gastronomy. Routledge. 
Hiernaux, D. and imelda Gonzalez, C. (2014), Tourism and gentrification: theoretical insights on articulation. Revista de Geografia Norte Grande, 28, 55-70

Ignatov, E. and Smith, S. (2006), Segmenting Canadian culinary tourists. Current Issues in Tourism 9 (3): 235-255.

Ilbery, B. et al. (2003), Quality products and services in the lagging rural regions of the European Union: A producer perspective. In Beesley K; Millward B and Ilbery B (eds) The new countryside: Geographic perspectives of rural change. Manitoba, Canada: Brandon University.

Jeon, M.; Kang, M. and Desmarais, E. (2016), Residents' Perceived Quality of Life in a Cultural-Heritage Tourism Destination. Applied Research Quality Life 11: 105123.

Jurowski, C., Uysal, M., \& Williams, R. (1997). A theoretical analysis of host community resident reactions to tourism. Journal of Travel Research, 36(2), 311.

Krajnc, D. and Glavic, P. (2005), How to compare companies on relevant dimensions of sustainability. Ecoogical Economics, 55, 551-563.

Keller, P. (2005), "A new Symbiotic Relationship between Culture, Leisure and Tourism in the Urban environment", World Tourism Organization Seminar Proceedings "The Future of City Tourism in Europe", Coimbra (Portugal), May.

Ko, D. W., \& Stewart, W. P. (2002). A structural equation model of residents' attitudes for tourism development. Tourism Management, 23(5), 521-530.

Krippendorf, J. (1977): Les deivoreurs de paysages. Le tourisme doit-il detruire les sites qui le font vivre?, 24 Heures, Lausanne.

Krippendorf, J. (1987), The Holiday Makers. Heinemann International: London.

Látková, P., \& Vogt, C. A. (2012). Residents' attitudes toward existing and future tourism development in rural communities. Journal of Travel Research, 51(1), $50-67$.

Liu, Z. (2003), Sustainable Tourism Development: A Critique. Journal of Sustainable Tourism 11 (6): 459-475.

Long, L. (2004), Culinary Tourism. UK: The University Press of Kentucky.

López Palomeque, F. (2007), Planificación territorial del turismo y sostenibilidad: fundamentos, realidades y retos in Anuario Turismo y Sociedad (VIII, 51-68). Facultad de Administración de Empresas Turísticas y Hoteleras. University of Colombia.

Lozano-Oyola, M., Blancas, F.J., González, M. and Caballero, R. (2012), Sustainable tourism indicators as planning tools in cultural destinations. Ecological Indicators, 18, 659-675.

Marozzi, P., Lima, J. y Sarmiento, M. (2011), Caracterización de los visitantes y determinación de la capacidad de carga turística en el Parque Nacional Los 
Cardones (PNLC). Salta, Argentina. Ciencia, 6 (22), 7-25.

Massiani, J. and Santoro, G. (2012), The relevance of the concept of capacity for the management of a tourist destinations: theory and application to tourism management in Venice, Rivista Italiana di Economia, Demografia e Statistica, LXVI (2), 141-156

Middleton, V.C. and Hawkins, R. (1998), Sustainable Tourism: A Marketing Perspective. Oxford: Butterworth-Heinemann.

Nelle, A.B. (2009), Museality in the urban context: An investigation of museality and musealisation processes in three Spanish-colonial World Heritage Towns. Urban Design International, 14 (3), 152-171

Nghi, T., Lan, N., Thai, N., Mai, D. and Thanh, D. (2007), Tourism carrying capacity assessment for Phong Nha - Ke Bang and Dong Hoi, Quang Binh province. VNU Journal of Science, Earth Sciences, 23, 80-87

Okumus, F., Kock, G., Scantlebury, G., \& Okumus, B. (2013). Using local cuisines when promoting small Caribbean Island destinations. Journal of Travel and Tourism Marketing, 30(4), 410-429.

Padin, C. (2012), A sustainable tourism planning model: Components and relationships. European Business Review 24(6): 510-518.

Petroncelli, Elvira (2008) Transformation process and spirit of the place: Historic ambits. In: 16th ICOMOS General Assembly and International Symposium: 'Finding the spirit of place - between the tangible and the intangible', 29 sept - 4 oct 2008, Quebec, Canada.

Puija, L. (2016), Cultural heritage and territory. Architectural tools for a sustainable conservation of cultural landscape, International Journal of Conservation Science, 7 (1), 213-218

Pulido, J.I. and Saìnchez, M. (2009). Measuring tourism sustainability: proposal for a composite index. Tourism Economics, 15 (2), 277-296.

Richards, G. (1996). Cultural Tourism in Europe. CAB International, Wallingford, UK.

Richards, G. (2012), Food and the Tourism Experience: The OECD-Korea Workshop. OECD Studies on Tourism, OECD publishing.

Ritchie, J.R. and Crouch, G.I. (2003), The Competitive Destination: A Sustainable Tourism Perspective. London: Cabi.

Robertson, R. (1992). Globalisation: Social Theory and Global Culture. Sage, London.

Saveriades, A. (2000). Establishing the social tourism carrying capacity for the tourist resorts of the east coast of the Republic of Cyprus. Tourism Management, 21, 147 $-156$.

Sayan, M. and Atik, M. (2011), Recreation Carrying Capacity Estimates for Protected Areas: A Study of Termessos National Park. Ekoloji, 20 (78), 66-74

Schlüter, C. y Drummond, J. (2012), Evaluación de la Capacidad de Carga Física del Parque Municipal del Itiquira, Formosa (Go), Brasil. Estudios y Perspectivas en 
Turismo, 21, 996-1012

Segrado, R., Arroyo, L., Amador, K., Palma, M. y Serrano, R. (2015), Hacia un Modelo de Aprovechamiento Turístico Sustentable en Áreas Naturales Protegidas: Estudio d Caso del Parque Natural Chankanaab de Cozumel, México, Pasos, Revista de Turismo y Patrimonio Cultural, 13 (1), 25-42

Segrado, R. y Arroyo, L. (2009), El Método de la Capacidad de Carga Turística Aplicado a la Medición de la Sustentabilidad de Cozumel, México. Revista TURyDES, 2 ( 5). Internet: http://www.eumed.net/rev/turydes/05/sa.htm $(08 / 03 / 2014)$.

Shelby, B., Vaske, J., and Heberlein, T. (1989), Comparative analysis of crowding in multiple locations: Results from fifteen years of research. Leisure Sciences, 11, 69-291.

Sirgy, M.; Widgery, R.; Lee, D. and Yu, G. (2010), Developing a measure of community wellbeing based on perceptions of impact in various life domains. Social Indicators Research 96: 295-311.

Stankey, G., McCool, S. and Stokes, G. (1984), Limits of acceptable change: a new framework for managing the Bob Marshall wilderness, Western Wildlands 10, 33-37. Stanley, J. and Stanley, L. (2015), Food Tourism. London: Cabi.

Touraine, A. (2005), Un nuevo paradigma; para comprender el mundo de hoy. Buenos Aires: Paidós.

Tsai, C.T. (2016), Memorable Tourist Experiences and Place Attachment When Consuming Local Food, International Journal of Tourism Research, 18 (6), 536548

Urry, J. (1990), The tourist gaze. London: Sage Publications.

Urry, J. (1995), Consuming places. London: Routledge.

Uysal, M.; Perdue, R. and Sirgy, R. (2012), Handbook of tourism and quality-of-life research: Enhancing the lives of tourists and residents of host communities. Netherland: Springer.

Vaske, J., and Donnelly, M. (2002), Generalizing the encounter-norm-crowding relationship. Leisure Sciences, 24, 255-269.

Wolf, E. (2002), Culinary Tourism: A Tasty Economic Proposition. Portland: International Culinary Tourism Taskforce.

World Commission on Environment and Development (1987), Our Common Future. New York, USA: Oxford University Press.

World Tourism Organization (2004), Indicators of Sustainable Development for Tourism Destinations: A Guidebook. Madrid: WTO.

UNEP, UNWTO, (2005). Making Tourism More Sustainable: A Guide for Policy Makers. Madrid: United Nations Environment Programme, World Tourism Organization.

Wall, G., 1997. Is ecotourism sustainable? Environment Management, 21 (4), 483-491. 
VVAA (2013), Herramienta del Sistema Europeo de Indicadores Turísticos para Destinos Sostenibles. UE: Comisión Europea, DG Empresa e Industria.

Zhou, Q., Zhang, J., Zhang, H., \& Ma, J. (2015). A Structural model of host authenticity. Annals of Tourism Research, 55, 28-45.

Zukin, S. (1998). Politics and aesthetics of public space: the" American" model. Real City, Ideal City. Meaning and Function in the Modern Urban Space.

Zukin, S. (1995). Whose culture? Whose city?. The urban sociology reader, 281-289. 